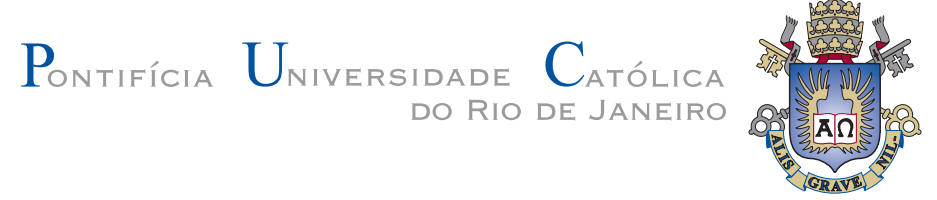

André Zaccur Uchôa Cavalcanti

\title{
Results of Ambrosetti-Prodi type for non-selfadjoint elliptic operators
}

Tese de Doutorado

Thesis presented to the Postgraduate Program in Matemática of the Departamento de Matemática do Centro Técnico Científico da PUC-Rio, as partial fulfillment of the requirements for the degree of Doutor em Matemática.

Advisor : Prof. Boyan Slavchev Sirakov

Co-Advisor: Prof. Carlos Tomei

Rio de Janeiro

March 2015 
André Zaccur Uchôa Cavalcanti

\section{Results of Ambrosetti-Prodi type for non-selfadjoint elliptic operators}

Thesis presented to the Postgraduate Program in Matemática of the Departamento de Matemática do Centro Técnico Científico da PUC-Rio, as partial fulfillment of the requirements for the degree of Doutor em Matemática. Approved by the following commission:

Prof. Boyan Slavchev Sirakov

Advisor

Pontifícia Universidade Católica do Rio de Janeiro

Prof. Carlos Tomei

Co-Advisor

Pontifícia Universidade Católica do Rio de Janeiro

Prof. Djairo Guedes de Figueiredo

Departamento de Matemática - UNICAMP

Prof. Eduardo Vasconcelos Oliveira Teixeira

Departamento de Matemática - UFC

Prof. Emanuel Augusto de Souza Carneiro IMPA

Prof. Flavio Dickstein

Departamento de Matemática - UFRJ

Prof. João Marcos Bezerra do Ó Departamento de Matemática - UFPB

Prof. Ricardo Sá Earp Departamento de Matemática - PUC-Rio

Prof. José Eugenio Leal Coordinator of the Centro Técnico Científico Pontifícia Universidade Católica do Rio de Janeiro 
All rights reserved. It is forbidden partial or complete reproduction without previous authorization of the university, the author and the advisor.

\section{André Zaccur Uchôa Cavalcanti}

Bibliographic data

Zaccur, André

Results of Ambrosetti-Prodi type for non-selfadjoint elliptic operators / André Zaccur Uchôa Cavalcanti; advisor: Boyan Slavchev Sirakov; co-advisor:Carlos Tomei . - 2015. $91 \mathrm{f}$. : il. ; $30 \mathrm{~cm}$

1. Tese (Doutorado em Matemática) - Pontifícia Universidade Católica do Rio de Janeiro, Rio de Janeiro, 2015.

Inclui bibliografia

1. Matemática - Teses. 2. Operadores elíticos. 3. Ambrosetti-Prodi. 4. equações não lineares. 5. dobras globais. I. Sirakov, Boyan. II. Tomei, Carlos. III. Pontifícia Universidade Católica do Rio de Janeiro. Departamento de Matemática. IV. Título. 


\section{Acknowledgments}

First of all I express my gratitude to my beloved wife who endured five long years by my side without ever questioning my choice of becoming a postgraduate Mathematics student.

I am extremely grateful to my mother, father, stepmother, stepfather, brothers, sister, grandmothers, grandfathers, aunts, uncles and cousins for the permanent support throughout these tough years.

To my esteemed professors Carlos Tomei, Boyan Sirakov, Ricardo Sá Earp, Frederico Palmeira and Nicolau Saldanha I leave my most sincere gratitude and affection.

To the caring team of the DMat Katia, Creuza, Fernanda, Orlando and Otávio, my many thanks for all these years of support.

I also refer to my supportive colleagues José Victor, Americo Cunha, Rodrigo Pacheco, Tiane Marcarini, Emília Alves, Dania Gonzáles, Yunelsi Nápoles, Byron, Pedro Millet, Paulo Orenstein, Miguel Orrillo, Miguel Schnoor, Kong Zhou, Edgar Matias, Yuri Ki, Gabrielle Saller, Lilian Brambila, Felipe Mello, Otávio Kaminski, Alessandro Gaio, João Paixão, Lis Ingrid, Debora Mondaini. My special thanks to Manoel Oliveira for being such a great friend.

I also thank Gilberto Nascimento, Ana Branco, Maria Angélica, Dr. Hans, Lucas and the teams of LARA I and Caravana do Amor without whom this program would probably have cost my sanity.

I am forever grateful to my beloved Father for the breath of life, the gift of faith and all these supportive people that have been by my side.

Lastly, I acknowledge CNPq and PUC-Rio for the financial support provided. 


\section{Abstract}

Zaccur, André; Sirakov, Boyan (Advisor); Tomei, Carlos (CoAdvisor). Results of Ambrosetti-Prodi type for nonselfadjoint elliptic operators. Rio de Janeiro, 2015. 91p. D.Sc. Thesis - Departamento de Matemática, Pontifícia Universidade Católica do Rio de Janeiro.

The celebrated Ambrosetti-Prodi theorem studies perturbations of the Dirichlet Laplacian by a nonlinear function jumping over the principal eigenvalue of the operator. Various extensions of this landmark result were obtained for self-adjoint operators, in particular by Berger-Podolak in 1975, who gave a geometrical description of the solution set. In this thesis we show that similar theorems are valid for non self-adjoint operators. We employ techniques based on the maximum principle, which even let us obtain new results in the self-adjoint setting. In particular, we show that the semilinear operator is a fold. As a consequence, we obtain exact count of solutions for these operators even when the perturbation is non-smooth.

\section{Keywords}

Elliptic operators; Ambrosetti-Prodi; non-linear equations; global folds; 


\section{Resumo}

Zaccur, André; Sirakov, Boyan; Tomei, Carlos. Resultados do tipo Ambrosetti-Prodi para operadores elíticos não autoadjuntos. Rio de Janeiro, 2015. 91p. Tese de Doutorado Departamento de Matemática, Pontifícia Universidade Católica do Rio de Janeiro.

O célebre teorema de Ambrosetti-Prodi estuda perturbações do Laplaciano sob condições de Dirichlet por funções não lineares que saltam sobre o autovalor principal do operador. Diversas extensões desse resultado foram obtidos para operadores auto-adjuntos, em particular por Berger-Podolak em 1975, que deram uma descrição geométrica do conjunto solução. Nós empregamos técnicas baseadas no princípio do máximo que nos permite obter novos resultados inclusive para o cenário auto-adjunto. Em particular, nós mostramos que o operador semi-linear é uma dobra global. Obtemos também uma contagem exata de soluções para esses operadores ainda quando a perturbação não é suave.

\section{Palavras-chave}

Operadores elíticos; Ambrosetti-Prodi; equações não lineares; dobras globais; 


\section{Contents}

$\begin{array}{lll}1 & \text { Introduction } & 9\end{array}$

2 Lipschitz nonlinearities $\quad 19$

$\begin{array}{lll}2.1 & \text { Lyapunov-Schmidt reduction } & 19\end{array}$

$\begin{array}{ll}2.2 & \text { Behaviour of fibers at infinity } \\ 2.3 & 27\end{array}$

$\begin{array}{ll}2.3 & \text { Behaviour of heights at infinity } \\ 2.4 & 28\end{array}$

$\begin{array}{lll}2.4 & \text { Criteria for properness } & 30\end{array}$

2.5 Proof of theorem 2.6 32

3 Differentiable Lipschitz nonlinearities $\quad 38$

$\begin{array}{lll}3.1 & \text { Regularity of fibers and heights } & 38\end{array}$

3.2 Singularities 40

4 A differentiable fold $\quad 45$

4.1 Sufficient conditions $\quad 45$

$\begin{array}{lll}4.2 & \text { Necessary conditions } & 49\end{array}$

4.3 An equivalence statement $\quad 53$

4.4 Geometry of heights for $C^{2}$ convex nonlinearities 54

$5 \quad$ A topological fold $\quad 57$

5.1 A count of solutions for convex Lipschitz nonlinearities 57

$\begin{array}{lll}5.2 & \text { An exact count of solutions } & 59\end{array}$

$6 \quad$ Technical tools $\quad 63$

6.1 Regularity of the nonlinearity 63

6.2 Proof of lemma $2.8 \quad 65$

6.3 Regularity of the principal eigenpair 66

$\begin{array}{ll}\text { Bibliography } & 72\end{array}$

$\begin{array}{ll}\text { A Regularization of real Lipschitz functions } & 75\end{array}$

$\begin{array}{ll}\text { B Spectral Theory } & 78\end{array}$

$\begin{array}{ll}C \text { Folds } & \mathbf{8 4}\end{array}$

C.1 Differentiable fold $\quad 84$

$\begin{array}{lll}\text { C.2 Topological fold } & 90\end{array}$ 


\section{List of Figures}

1.1 The components $R_{0}$ and $R_{2}$ are taken diffeomorphically to $S_{2}$. 11

1.2 The point $z+t_{c} \phi_{1}$ is a critical point of $F \circ \Phi$. 15

2.1 The function $F \circ \Phi$ trivializes the first coordinate. 20

4.1 Here, $u_{k}\left(\epsilon_{+}\right)=u\left(s_{k}, l_{k}, r+\epsilon\right)$ and $u_{k}\left(\epsilon_{-}\right)=u\left(s_{k}, l_{k}, r-\epsilon\right) . \quad 53$

6.1 The image of $\xi_{\mid \sigma\left(-L-q\left(u_{0}\right)\right)}$. 67 